\title{
K-Ar age determinations of some Miocene-Pliocene basalts in Israel: their significance to the tectonics of the Rift Valley
}

\author{
G. STEINITZ, Y. BARTOV \& J. C. HUNZIKER
}

Summary. Thirty samples of Upper Tertiary basalts intruding marine and continental sequences were dated by the K-Ar method. Four volcanic phases are recorded: (a) $24.8 \pm 1.5 \mathrm{Ma}$ of the Raqabat e Na'ame dike in Central Sinai; (b) 20.4 \pm 0.7 Ma of basalt intrusions in Central Sinai and the Arava. Some of these are offset by E-W to NE-SW dextral faults of the Central Sinai - Negev Shear Zone; (c) $14.5 \pm 0.3$ to $4.9 \pm 1.3$ Ma of basalt flows in the Eastern Galilee and the Coastal Plain; (d) $2.7 \pm 0.6 \mathrm{Ma}$ of 'En Yahav dike. These results contribute to the correlation between Tertiary continental formations from different areas, and put limits on the age of tectonic events, such as folding in the Syrian arc, faulting in the Central Sinai - Negev Shear Zone and shearing along the Jordan Rift.

\section{Introduction}

The present tectonic pattern of the Jordan rift valley and its surroundings have been shaped mainly in the Upper Tertiary and Quaternary periods (Picard, 1943).

Erosional periods and continental sedimentation are typical to the area during this time span. As only minor ingressions of the marine environment exist, the exact stratigraphic control on the sediments and the precise determination of the tectonic phases must depend on other methods. Widespread occurrences of volcanic bodies, with the aid of $\mathrm{K}-\mathrm{Ar}$ dating, assist in limiting the ages of the stratigraphic and tectonic events.

New K-Ar age determinations have been made on Tertiary basalts in Israel and Sinai (Fig. 1). Previous $\mathrm{K}-\mathrm{Ar}$ age determinations on parts of these sequences were published by Siedner (1973) and by Siedner \& Horowitz (1974). In the present study all samples (except those from 'En Yahav) are fine-grained, alkaline, olivine basalts.

Argon was extracted together with a ${ }^{38} \mathrm{Ar}$ spike, in a glass line. The isotopic ratios were measured on an improved Varian Mat GD-150 mass spectrometer at the KAW laboratory, Bern. Potassium was determined by atomic absorption (Perkin Elemer 460) at the Hebrew University, Jerusalem. The decay constants used are:

$$
\lambda_{\beta}=0.4963 \times 10^{-9}, \quad \lambda_{\varepsilon}=0.581 \times 10^{-10} .
$$

For the atomic abundance of ${ }^{40} \mathrm{~K}$, the value of $1.194 \times 10^{-4}$ mole ${ }^{40} \mathrm{~K} / \mathrm{K}$ was used.

During the analytical procedure values close to 295.5 were measured for ${ }^{40} \mathrm{Ar} /{ }^{36} \mathrm{Ar}$ in atmospheric argon. This value was used in the calculation of the point ages. The $2 \sigma$ error on the latter is estimated to be $2 \%$. Isochron ages were calculated according to Wendt (1969).

\section{Results}

\section{2.a. The Lower Basalt and the Herod Formation (Fig. 2)}

The Lower Basalt (Blake, 1928) consists of a sequence of flows which interfinger with the lacustrine Herod Formation (Schulman, 1959). The latter is exposed in Eastern Galilee, along the rift fault escarpments and beyond them, as well as on the eastern coast of the Sea of Galilee (Michelson, 1972). The outcrops extend southwards to Marma Feiyad (Schulman \& Rosenthal, 1968).

For the present investigation two flows (the lowermost and the uppermost) were sampled at the $400 \mathrm{~m}$ thick section of the Herod Formation at Poriya, south of Tiberias. This sequence 


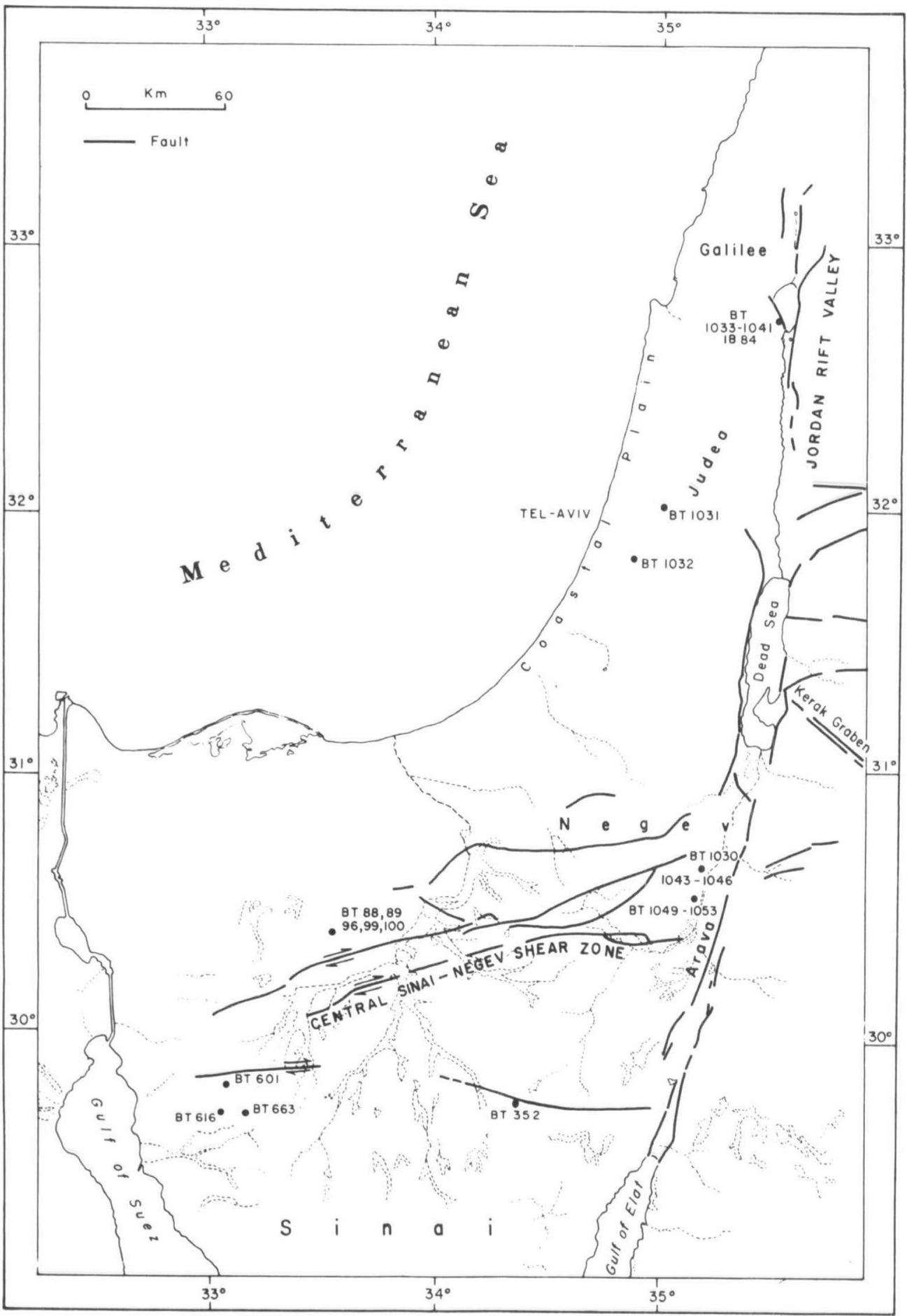

Figure 1. Sample distribution and main tectonic elements referred to in the text. IB84, BT 1033-1041Lower Basalt, S of Tiberias. BT 1031 - Shukba. BT 1032 - Hulda (N. Hashlosha). BT 1030, BT 1043-1046 - 'En Yahav. BT 1049-1053 - N. Ashosh. BT 88, 89, 96, 99, 100 - Gebel Iktepa. BT 601, 616, 663 - Raqabat e Naame. BT 352 - Thamad. 
En Yohov

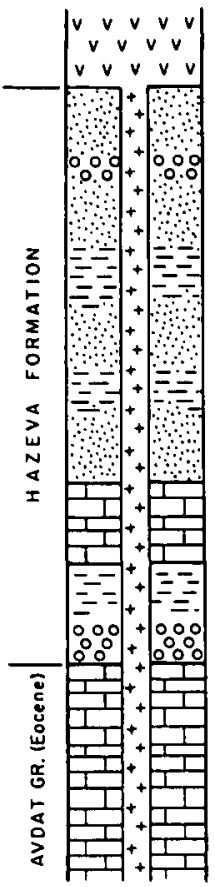

Huldo

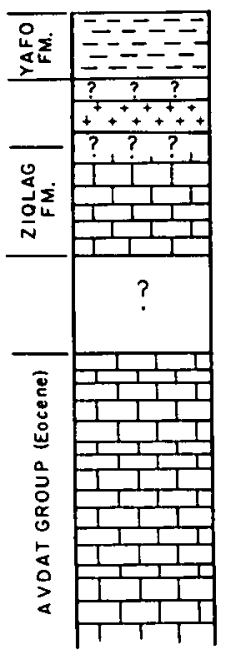

Shukbo

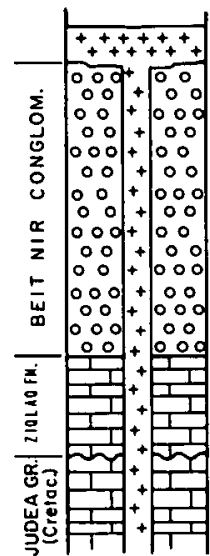

Tiberios

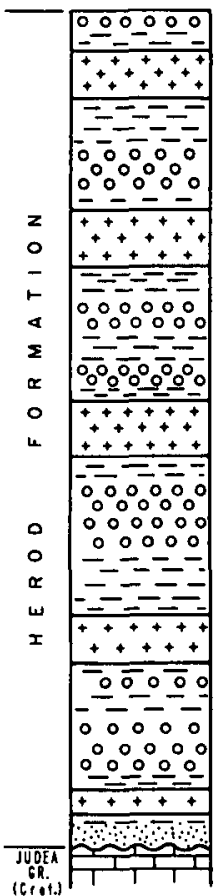

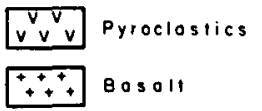
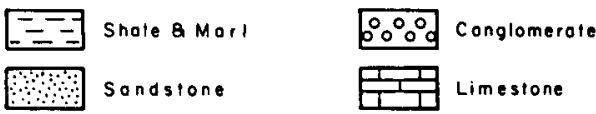

Not to scole

Figure 2. The stratigraphic relations of some of the samples.

unconformably overlies Turonian strata and is dominated by 'red beds' composed of marls and conglomerates, the pebbles and boulders of which are derived mainly from marine Eocene strata.

Siedner \& Horowitz (1974) concluded that all flows of the Lower Basalt are practically coeaval, attributing to them an age between 12.2 and $14.6 \mathrm{Ma}$. The present investigation gives the lower flow point ages from $10.3( \pm 2.0)$ to $15.6( \pm 1.6) \mathrm{Ma}$. (Table 1). The point ages for the upper flow range from $5.6( \pm 0.6)$ to $6.4( \pm 1.3)$ Ma. The resulting isochrons define ages of $14.5 \pm 0.3 \mathrm{Ma}$ for the lower flow (the somewhat low initial ratio requires further investigations) and 4.9 $\pm 1.3 \mathrm{Ma}$ for the upper flow (Figs 3,4). Similar ages (12.3-6.8 Ma) are given by Brown (1970) for a sequence of basaltic flows in Wadi Sirhan (NW Saudi Arabia). Thus it can be concluded that the Herod Formation was deposited in a continental basin during a time span of some $10 \mathrm{Ma}$, with a mean rate of sedimentation of $40 \mathrm{~m}$ per $1 \mathrm{Ma}$.

\section{2.b. Shukba dike and Hulda volcanics (Fig. 2)}

The Shukba dike and the Hulda volcanics are part of a widespread coastal plain volcanic field (National Park volcanics; Grader \& Gvirtzman, 1961).

The Shukba dike, situated on the western flank of the Ramalla anticline (Livnat, unpubl. thesis, Hebrew Univ., Jerusalem, 1971) intruded the Beit Nir conglomerate which is assumed to represent an Upper Miocene fluvial phase (Gvirtzman \& Buchbinder, 1969). The Beit Nir 
Table 1

\begin{tabular}{|c|c|c|c|c|c|c|c|}
\hline Sample & Location & $\begin{array}{c}{ }^{40} \mathrm{Ar} \mathrm{rad} \\
\left(\mathrm{cm}^{3} \mathrm{~g}^{-1}\right. \\
\left.\mathrm{STP} \times 10^{-6}\right)\end{array}$ & $\% \mathrm{rad}$ & $\% \mathrm{~K}$ & ${ }^{40} \mathrm{~K} /{ }^{36} \mathrm{Ar} \times 10^{3}$ & ${ }^{40} \mathrm{Ar} /{ }^{36} \mathrm{AR}$ & Age (ma) \\
\hline BT 1033 & $\begin{array}{l}\text { Tiberias, L. B., } \\
\text { lower flow }\end{array}$ & 0.3371 & 21.3 & 0.789 & 125.56 & 375.73 & $11.0 \pm 1.5$ \\
\hline BT 1034 & & 0.4343 & 38.8 & 0.784 & 226.34 & 483.00 & $14.2 \pm 1.1$ \\
\hline BT 1036 & & 0.3060 & 15.0 & 0.765 & 87.56 & 347.89 & $10.3 \pm 2.0$ \\
\hline BT 1038 & & 0.4620 & 37.3 & 0.907 & 231.33 & 471.72 & $13.1 \pm 1.0$ \\
\hline BT 1037 & & 0.7491 & 57.6 & 1.38 & 494.18 & 696.55 & $13.9 \pm 0.7$ \\
\hline IB 84 & & 0.5044 & 28.7 & 0.826 & 125.86 & 400.37 & $15.6 \pm 1.6$ \\
\hline BT 1039 & $\begin{array}{l}\text { Tiberias, L. B., } \\
\text { upper flow }\end{array}$ & 0.1803 & 25.2 & 0.822 & 312.32 & 398.04 & $5.6 \pm 0.7$ \\
\hline BT 1040 & & 0.2085 & 15.4 & 0.833 & 143.96 & 349.40 & $6.4 \pm 1.3$ \\
\hline BT 1041 & & 0.2105 & 18.6 & 0.871 & 186.78 & 363.08 & $6.2 \pm 1.0$ \\
\hline BT 1031 & Shukba (dike) & 0.1991 & 8.2 & 1.09 & 96.94 & 321.99 & $4.7 \pm 1.7$ \\
\hline BT 1053 & N. Ashosh (plug) & 0.3533 & 16.1 & 0.477 & 51.21 & 352.22 & $19.0 \pm 3.5$ \\
\hline BT 1049 & & 0.3231 & 17.8 & 0.433 & 57.44 & 359.54 & $19.1 \pm 3.2$ \\
\hline BT 1052 & & 0.3943 & 14.3 & 0.472 & 39.52 & 344.87 & $21.4 \pm 4.5$ \\
\hline BT 1050 & & 0.3870 & 28.8 & 0.487 & 100.59 & 415.02 & $20.3 \pm 2.1$ \\
\hline BT 1051 & & 0.3431 & 16.3 & 0.483 & 54.17 & 353.00 & $18.2 \pm 3.3$ \\
\hline BT 601 & W. Nutila (dike) & 0.5442 & 5.2 & 0.449 & 8.91 & 311.63 & $30.9 \pm 17.9$ \\
\hline BT 616 & Raqabat e Na'ame & 0.5152 & 23.1 & 0.52 & 59.87 & 384.19 & $25.3 \pm 3.3$ \\
\hline BT 663 & & 0.4284 & 2.2 & 0.387 & 4.09 & 302.25 & $28.2 \pm 37.9$ \\
\hline BT 1032 & $\begin{array}{c}\text { Hulda (Nahal } \\
\text { Hashlosha) }\end{array}$ & 0.2982 & 25.4 & 1.12 & 252.99 & 396.24 & $6.8 \pm 0.8$ \\
\hline BT 1043 & 'En Yahav (dike) & 0.1705 & 23.5 & 0.924 & 329.25 & 386.42 & $4.7 \pm 0.6$ \\
\hline BT 1044 & & 0.4235 & 15.6 & 1.235 & 106.39 & 350.03 & $8.8 \pm 1.7$ \\
\hline BT 1045 & & 0.1912 & 19.8 & 1.25 & 319.79 & 368.73 & $3.9 \pm 0.6$ \\
\hline BT 1046 & e & 0.2128 & 23.2 & 1.07 & 299.67 & 384.68 & $5.1 \pm 0.7$ \\
\hline BT 1030 & & 0.1698 & 15.9 & 0.898 & 197.31 & 351.34 & $4.9 \pm 0.9$ \\
\hline BT 88 & Gebel Iktefa (dike) & 0.2378 & 2.5 & 0.314 & 6.77 & 303.17 & $19.4 \pm 23.0$ \\
\hline BT 89 & & 0.7045 & 9.7 & 0.761 & 23.10 & 327.42 & $23.6 \pm 7.3$ \\
\hline BT 96 & & 1.0091 & 40.1 & 1.28 & 168.04 & 493.53 & $20.2 \pm 1.5$ \\
\hline BT 99 & & 0.3133 & 23.6 & 0.378 & 73.58 & 386.72 & $21.2 \pm 2.7$ \\
\hline BT 100 & & 0.6023 & 34.4 & 0.608 & 101.34 & 435.38 & $25.3 \pm 2.2$ \\
\hline BT 352 & Thamad (plug) & 1.0490 & 17.7 & 0.863 & 33.96 & 347.04 & $30.9 \pm 5.2$ \\
\hline
\end{tabular}

conglomerate, which is known from outcrops in the Coastal Plain and Hashefela region, contains pebbles which are derived from Cretaceous to Tertiary rocks. In this vicinity it overlies the marine Ziqlag Formation (Upper Miocene; Buchbinder, unpubl. thesis, Hebrew Univ., Jerusalem, 1975). The point age of this dike (one sample) is $4.7 \pm 1.7 \mathrm{Ma}$ (Table 1).

The basaltic body exposed in the vicinity of Hulda (Nahal Hashlosha) overlies the Ziqlag Formation. It is probably also younger than the base of the younger Yafo Formation (Gvirtzman \& Buchbinder, 1969). The point age for the single sample analysed is $6.8 \pm 0.8 \mathrm{Ma}$. (Table 1).

The points for the Shukba dike and Hulda volcanics fall near the isochron of the Upper flow of the Lower basalt (Fig. 4). As a result of the measured point ages it can be established that the Ziqlag Formation is older than $6.8( \pm 0.8) \mathrm{Ma}$ and that the base of the Beit Nir conglomerate is older than $4.7( \pm 1.7) \mathrm{Ma}$. This is in accordance with existing stratigraphic data. 


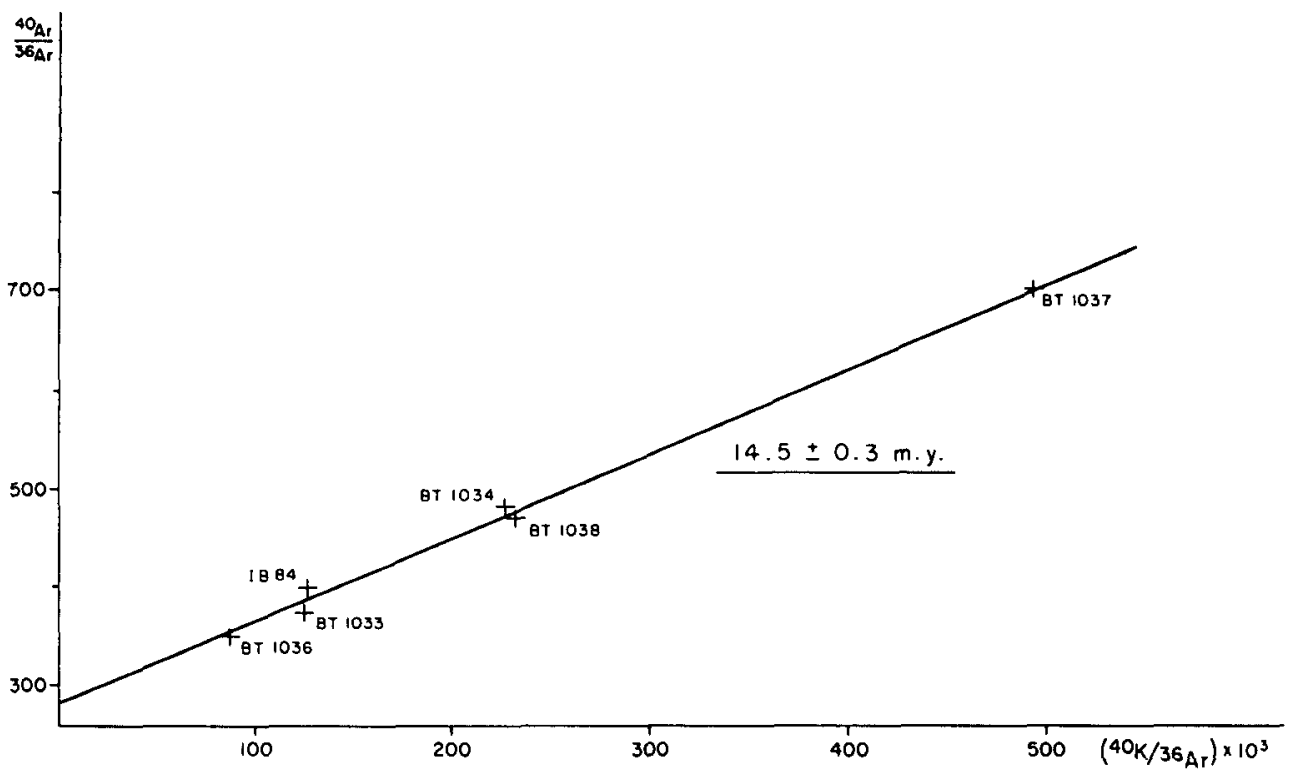

Figure 3. Isochron of the Lower Basalt, lower flow.

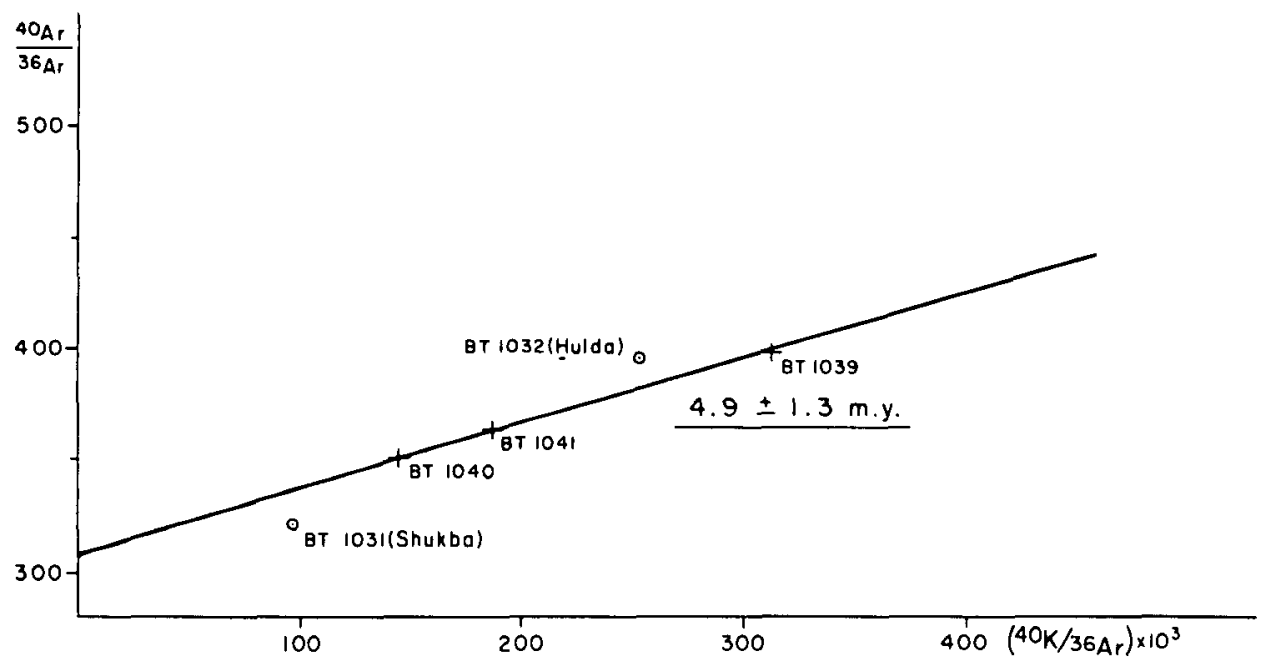

Figure 4. Isochron of the Lower Basalt, upper flow.

\section{2.c. 'En Yahav dike (Fig. 2)}

The 'En Yahav dike, oriented in an E-W direction, is situated on the western margins of the Arava rift valley (Bentor \& Vroman, 1957). The rock determined as tanbushite (Levitte, unpubl. thesis, Hebrew Univ., Jerusalem, 1966) intrudes Middle Eocene strata and is accompanied by pyroclastics consisting of tuff and some volcanic bombs. These pyroclastics are younger than most of the continental Hazeva Formation, and it seems that they constitute the topmost beds of this formation.

The present analysis yields point ages of $3.9( \pm 0.5)$ to $8.8( \pm 1.7) \mathrm{Ma}$ for the basalts of the 'En Yahav dike (Table 1). The isochron yields an age of $2.7 \pm 0.6 \mathrm{Ma}$ (Fig. 5). This isochron is the only one exhibiting a significantly high $(331 \pm 16){ }^{40} \mathrm{Ar} /{ }^{36} \mathrm{Ar}$ initial value. The low age and 


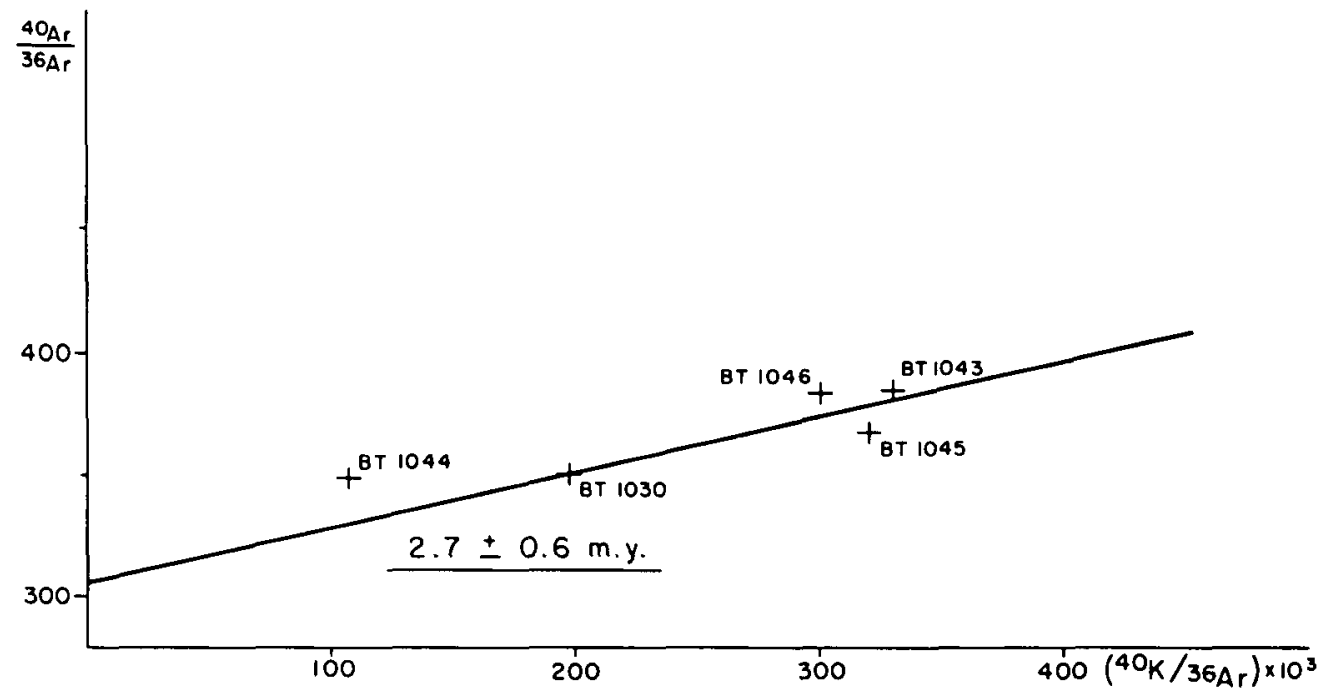

Figure 5. Isochron of the 'En Yahav dike.

the high initial value are influenced by sample BT 1044. Deleting this sample yields an isochron age of $3.9 \mathrm{Ma}( \pm 2.6)$ with a normal initial ratio. At this stage the authors prefer to attribute the age indicated by the first isochron to the topmost beds of the Hazeva Formation. The evaluation and implications of such a result are given in the discussion.

\section{2.d. The Ashosh plug}

A basaltic plug, accompanied by tuffs (Levitte unpubl. thesis, Hebrew Univ., Jerusalem, 1966), is intruded into Middle Eocene strata at a location $12 \mathrm{~km} \mathrm{~S}$ of the 'En Yahav dike. Together with the 'En Yahav dike, it constitutes the only Tertiary volcanic occurrences along the southern part of the Jordan-Arava rift. The point ages of the Ashosh plug range from $18.2( \pm 3.3)$ to 21.3 ( \pm 4.5 ) Ma. The isochron yields an age of $20.7 \pm 2.2 \mathrm{Ma}$ (Fig. 6).

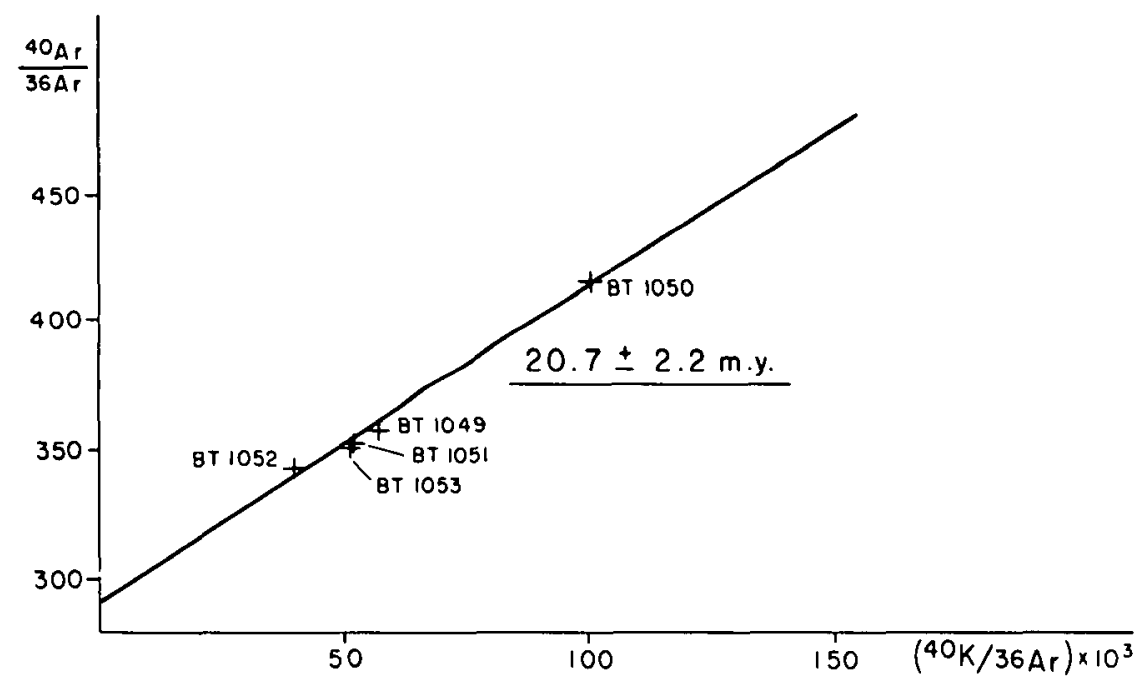

Figure 6. Isochron of the Ashosh plug. 


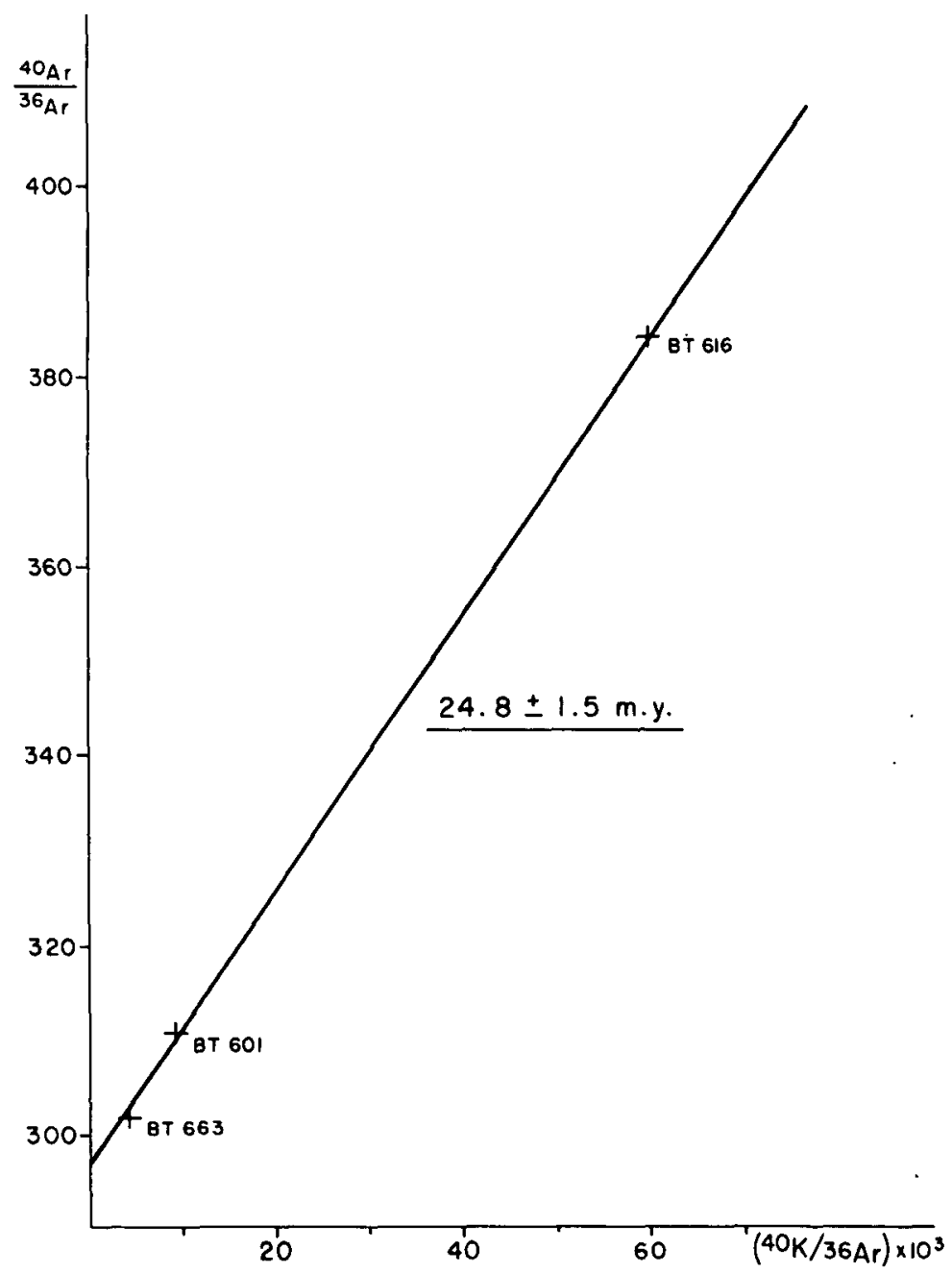

Figure 7. Isochron of the Raqabat e Na'ame dike complex.

\section{2.e. Basalts from Central Sinai}

Tertiary volcanic rocks are widespread in Central Sinai. Most occurrences are of doleritic dikes, sills and plugs. Some of the dikes are tens of $\mathrm{km}$ long (e.g. Raqabat e Na'ame). These bodies intrude rocks having ages up to Middle Eocene. Basaltic flows are known from Wadi Taiba area in western Sinai as well as from the vicinity of the Cairo-Suez road in Egypt. The latter were dated as 20-28 Ma old by Meneisy \& Kreuzer (1974).

The Raqabat e Na'ame dike trends E-W, parallel to a large fault belonging to the Central Sinai-Negev Shear Zone (Fig. 1). Its point ages vary from $25.3( \pm 3.3)$ to $30.9( \pm 17.9) \mathrm{Ma}$ (Table 1), and its isochron defines an age of $24.8 \pm 1.5 \mathrm{Ma}$ (Fig. 7).

Some of the dikes in Sinai are dextrally offset at several localities by E-W trending faults of the Central Sinai-Negev Shear Zone. The Gebel Iktefa dike is such a dike, being dextrally displaced $2.2 \mathrm{~km}$ by the Minshera fault (Bartov, unpubl. thesis, Hebrew Univ., Jerusalem, 1974). The point ages of this dike are from $20.2( \pm 1.5)$ to $25.3( \pm 2.2)$ Ma (Table 1). The isochron yields 


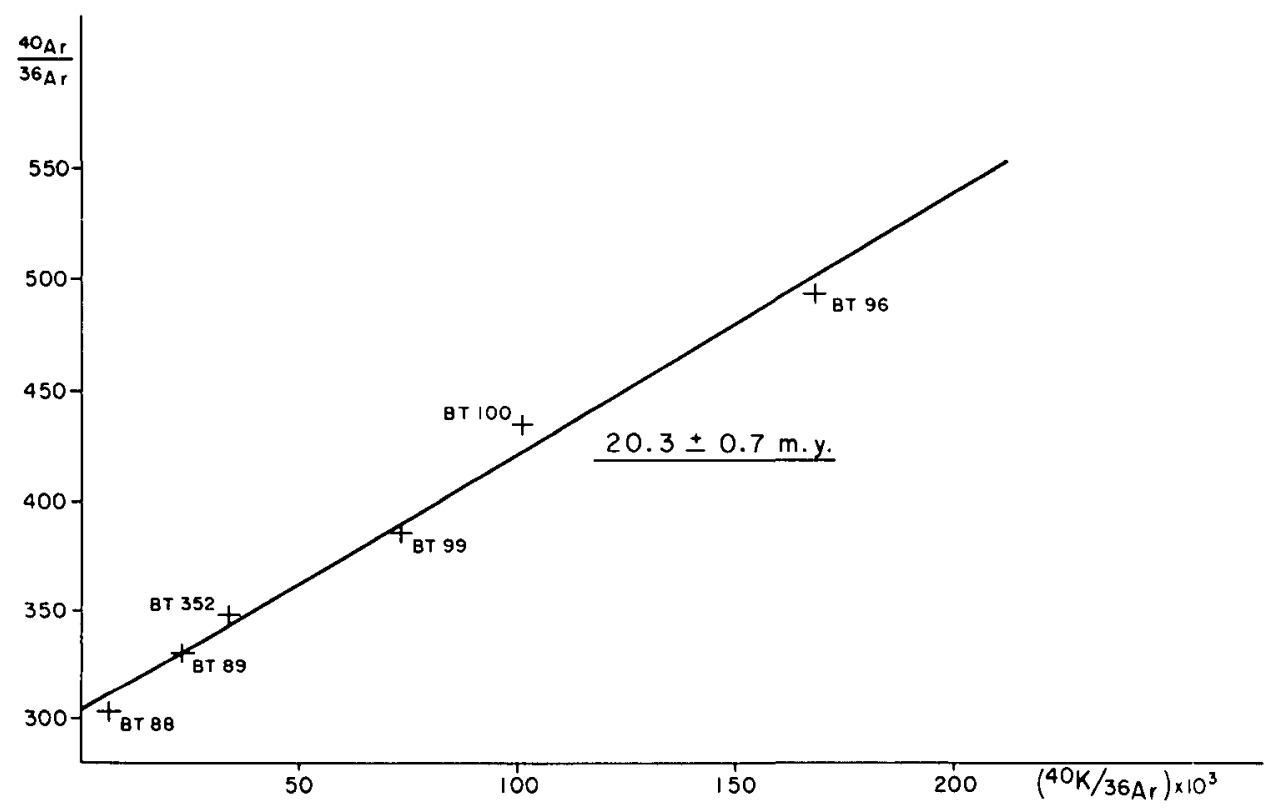

Figure 8. Isochron of the Gebel Iktefa dike.

Table 2. Compilation of K-Ar isochron ages

\begin{tabular}{|c|c|c|c|}
\hline Rock unit & $\begin{array}{l}\text { Isochron age } \\
\text { (Ma) }\end{array}$ & Error on age & $\begin{array}{c}\text { Initial }{ }^{36} \mathrm{Ar} /{ }^{40} \mathrm{Ar} \\
\quad+\text { error }\end{array}$ \\
\hline $\begin{array}{l}\text { 1. Tiberias, Lower Basalt, } \\
\text { lower flow }\end{array}$ & 14.5 & 0.3 & $280 \pm 10$ \\
\hline $\begin{array}{l}\text { 2. Tiberias, Lower Basalt, } \\
\text { upper flow }\end{array}$ & 4.9 & 1.3 & $308 \pm 12$ \\
\hline 3. 'En Yahav & 2.7 & 0.6 & $329 \pm 8$ \\
\hline $\begin{array}{l}\text { 4. 'En Yahav (excluding } \\
\text { BT 1044) }\end{array}$ & 3.9 & 2.4 & $308 \pm 39$ \\
\hline 5. Gebel Iktefa dike & 20.0 & 0.7 & $298 \pm 2$ \\
\hline $\begin{array}{l}\text { 6. Gebel Iktefa dike } \\
\text { (including BT 100) }\end{array}$ & 20.5 & 0.7 & $300 \pm 2$ \\
\hline $\begin{array}{l}\text { 7. Gebel Iktefa and Thamad } \\
\text { (including BT 100, BT 352) }\end{array}$ & 20.3 & 0.7 & $302 \pm 2$ \\
\hline 8. Ashosh plug & 20.7 & 2.2 & $291 \pm 7$ \\
\hline $\begin{array}{l}\text { 9. Ashosh plug + Gebel lktepa } \\
\text { (all } 11 \text { point isochron) }\end{array}$ & 20.4 & 0.7 & $297 \pm 2$ \\
\hline 10. Raqabat-e-Na'ame dike & 24.8 & 1.5 & $295 \pm 2$ \\
\hline
\end{tabular}

an age of $20.5 \pm 0.7 \mathrm{Ma}$ (Fig. 8). Therefore it is concluded that dextral movement along the faults of the Central Sinai-Negev Shear Zone is younger than $20.5 \mathrm{Ma}$.

One sample has been collected from a small plug, $\mathrm{E}$ of Thamad. This plug is situated within a graben, trending NNW, $1.5 \mathrm{~km}$ wide and showing some $60 \mathrm{~m}$ of vertical displacement. This graben is one of many NNW trending grabens in central Sinai, some of which exhibit similar volcanic bodies. A similar situation is also known from the Kerak Graben in Jordan (Bender, 1968). The occurrences of these volcanics are interpreted as genetically connected with the formation of the grabens; thus the age of these volcanics dates the age of the grabens. The point age of this body is $30.9 \pm 5.2 \mathrm{Ma}$, but as this point falls on the Gebel Iktefa isochron (BT-352, Fig. 8) we tend to attribute an age of $20.5 \pm 0.7 \mathrm{Ma}$ to it. 


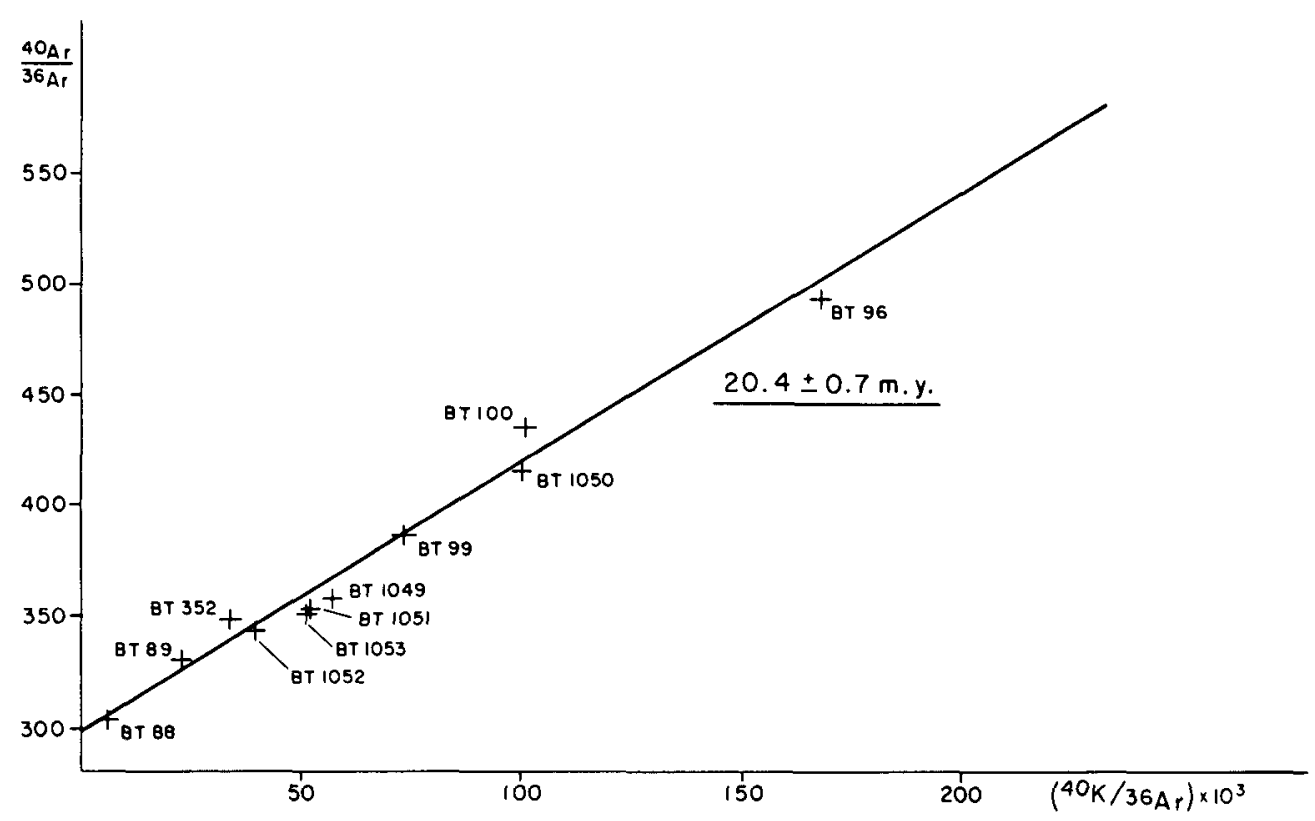

Figure 9. Isochron of the Ashosh plug and the Gebel lktefa dike.

\section{Discussion}

\section{3.a. Volcanism}

The earliest here recorded volcanic event occurs in Sinai (24.8 $\pm 1.5 \mathrm{Ma})$. A further event, around $20 \mathrm{Ma}$, led to the formation of isolated bodies (dikes, sills) distributed over a wide area in Sinai and in the Arava. The isochrons for the Iktefa dike and the Ashosh plug (and the Thamad plug) actually define one isochron (Fig. 9) establishing the correlation between these bodies. In the northern part of the country, the Tertiary volcanic activity started around 14.5 Ma ago, and continued through the Tertiary into the Pleistocene period. In the Coastal Plain, volcanism can at this stage be demonstrated only for an age of 5-7 Ma. A single, local, renewal of volcanic activity is noted in the Arava around $3 \mathrm{Ma}$.

\section{3.b. The Tertiary phase of continental fluviatile sedimentation}

The Tertiary Hazeva Formation is widely developed in the Negev and Central Sinai, being restricted to structural lows of synclines and grabens (Bentor \& Vroman, 1957; Garfunkel \& Horowitz, 1966). This continental formation, which is composed of a clastic sequence of conglomerate, sandstone, shales and carbonates is uniform in its appearance within the studied area. It shows lithological resemblance to other Tertiary clastic sequences in the Middle East such as the Herod Formation (Schulman, 1959) in Northern Israel, the Raham Conglomerate in Southern Israel (Garfunkel et al. 1974) and the Moghra Formation (Said, 1962) in Egypt. Similarities are also noted with the Marada Formation (Selly, 1969) in North Africa and the Raghama Formation (Brown, 1970) in Saudi Arabia.

Direct evidence for the age of the Hazeva Formation is rather poor. A Burdigalian age was ascribed to mammal remains which were found in the lower part of this formation at the Yeroham basin in the Northern Negev (Savage \& Tchernov, 1968). Similar assemblages have been dated as 22.5 Ma in East Africa (Bishop, Miller \& Fitch, 1969) and in North Africa (Savage \& Hamilton, 1973).

Interfingering between the Hazeva Formation and the marine Neogene of the Coastal Plain 
was recorded by Gvirtzman \& Buchbinder (1969) and dated by Derin \& Reiss (1973) as Serravallian to Tortonian. Horowitz (1974) suggested the Top Conglomerate of the Hazeva Formation as correlative to the Beit Nir conglomerate of the Coastal Plain.

A complication is introduced by the fission track dating of the Mottled Zone thermal event (Kolodny, Bar \& Sass, 1971). This event was measured on apatites from the Northern Judean Desert as $13.6( \pm 2.0) \mathrm{Ma}$ or $16.8( \pm 2.0) \mathrm{Ma}$ (dependent on the constants used). On the assumption that the thermal event of the Mottled Zone is synchronous in all its outcrops, Kolodny, Schulman \& Gross (1973) assigned an age between 9 and 13.5 Ma to a conglomerate, affected by the thermal event and situated in the Southern Judean Desert. This conglomerate is assumed by the authors to belong to the Top Conglomerate of the Hazeva Formation. Similar conglomerates are known in the Hazeva Formation in nearby areas (Shahar, 1973) and it may very well be that the conglomerate dated was not the Top Conglomerate of the formation.

No evidence is known for the Rift Valley to exist as such during the deposition of the Herod and the Hazeva Formations. In the case of the latter, the exposed sequences within the rift and in the Negev are consistent in terms of lithology and thickness. Garfunkel \& Horowitz (1966) suggested that the Hazeva Formation was deposited in inland basins connected by a river system which drained Transjordan and which flowed through the Arava. They considered the central part of the Arava to be a tectonic basin due to movements along the rift, based upon the great thickness of the Hazeva in that area. The only place where such a thickness was recorded is in the Arava 1 borehole ( $25 \mathrm{~km} \mathrm{~S}$ of the Dead Sea). Various authors interpret this borehole, passing through continental sediments, in different ways (e.g. Neev \& Emery, 1967; Zak, unpubl. thesis, Hebrew Univ., Jerusalem, 1967). The present authors suggest that the determination of the Hazeva Formation in the drilled section is not conclusive. Furthermore, the drilled section may well represent a section younger than the Hazeva Formation.

A rough correlation between the Herod Formation in Galilee, the Ziqlag Formation and Beit Nir Conglomerate in the Coastal Plain and the Hazeva Formation has previously been suggested (Gvirtzman \& Buchbinder, 1969; Kolodny et al. 1973; Horowitz, 1974). The data presented here substantiate this view and refine the picture by setting limiting values to this widespread phase of fluviatile sedimentation. This phase, best dated at this stage for the Herod Formation, extends over a time-span of some $10 \mathrm{Ma}$. Lacking better data at this stage, its upper limit is around $5 \mathrm{Ma}$ in Galilee and of a similar age in the Coastal Plain. For the Negev and the Arava, a younger upper limit seems to be possible - i.e. $3 \pm 1.0 \mathrm{Ma}$.

\section{3.c. Tectonic implications}

3.c.1. Folding in the Syrian arc

The relationship between the continental fluviatile phase and the Tertiary folding events of the Syrian arc (Krenkel, 1924) varies. In the Northern Negev (e.g. Ramon, Hazera, etc.), the Hazeva Formation postdates the main phase of folding (e.g. Freund \& Zak, 1973). Accepting the above-mentioned correlations, an upper limit for the age of folding in this area is set by assuming an age of at least 14-16 Ma for the base of the Hazeva Formation. On the other hand, it is observed that the Ziqlag Formation and Beit Nir Conglomerate, take part in the main folding of the western flank of the Ramallah and Hebron anticlinoria. A similar situation for the Hazeva Formation is described from the eastern side of the Hebron anticlinorium (Freund, 1965). Thus, a much younger age has to be ascribed to this folding event. The relationship between the Herod Formation and folding in the Galilee is inconclusive. 


\section{3.c.2. Faulting in the Central Sinai - Negev Shear Zone}

A continuous system of E-W to NE-SW orientated, dextral strike slip faults exists between the major faults of the Jordan and the Suez Rifts. Vertical displacements up to $1000 \mathrm{~m}$ and dextral offsets of up to $2.5 \mathrm{~km}$ were observed along faults of this zone. The main evidence for the lateral displacement is the offset of basalt dikes. Many of the occurrences of the Hazeva Formation in the Central Negev and Central Sinai are in structural lows along the Central Sinai Negev Shear Zone. No evidence for the pre-Hazeva Formation strike slip faulting is found along this zone. Therefore, it is suggested that the lateral movement postdates the Hazeva Formation, although the development of the tectonic lineaments could be of an earlier age.

\section{3.c.3. The Jordan Rift Valley}

None of the volcanic events dated in the present work can be directly related to a structural time table of the rift development. However, a contribution to the establishment of such a time table can be provided by two fault zones on both sides of the Rift.

A fault zone, similar to the Central Sinai - Negev Shear Zone, running E-W and NE-SW is known E of the Jordan Rift Valley (Fig. 1). According to Quennell (1951), Burdon (1959) and Bender (1968) these faults have dextral offsets. No age is attributed to the movement along them.

Based upon the similar geometry (spacing between faults, orientation) it is believed that the fault zone in Transjordan is an extension of the Central Sinai - Negev Shear Zone, now displaced some $106 \mathrm{~km}$ along the Rift (Quennell, 1951).

As to the age relations and history of movement, two possibilities exist:

(1) Quennell (1959) and Freund, Zak \& Garfunkel (1968) suggested that two principal phases of sinistral wrench faulting occurred along the Jordan Rift Valley. The first is thought to have lasted from the Mesozoic to the Miocene, resulting in a total displacement of about $60 \mathrm{~km}$. A further movement of about $40-45 \mathrm{~km}$ is of post-Miocene age. The average rate of movement since the Pliocene suggested by Freund et al. (1968) is $0.35 \mathrm{~cm} \mathrm{yr}^{-1}$. Using such a model and the present age data for the top of the Herod Formation and the top of the Hazeva Formation, we find rates of $0.9-1.5 \mathrm{~cm} \mathrm{yr}^{-1}$.

(2) It is difficult to accept an independent dextral movement on the offset E-W Shear Zone in Central Sinai and in Transjordan. Thus, if the shearing along the Central Sinai - Negev Shear Zone is prior to the present $106 \mathrm{~km}$ sinistral offset along the Jordan Rift, the whole latter movement is later than the Hazeva Formation (Bartov, unpubl. thesis, Hebrew Univ., Jerusalem, 1974). Again, using the presented age data for the top of the Herod and Hazeva Formation, average rates of movement of $2.2-3.5 \mathrm{~cm} \mathrm{yr}^{-1}$ are arrived at.

Acknowledgements. This research was conducted while G. S. was at Bern on a postdoctoral fellowship from the Hebrew University, Jerusalem. We thank M. Greenberg from the G.S.I. for help in preparation of samples; Drs A. Katz and A. Starinsky and M. Bielski from the Department of Geology, Hebrew University, for potassium determinations; E. Frank, W. Morauf and P. Stille for help with the Ar measurements. Y. Arkin and Professor R. Freund helped with the MS. Support was received from the 'Schweizerische Nationalfond'.

\section{References}

Bender, F. 1968. Geologie von Jordanien. Berlin: Gebruder Borntraeger.

Bentor, Y. K. \& Vroman, A. 1957. The Geological Map of the Negev, 1:100,000, Sheet 19: Arava Valley, with explanatory notes. Geol. Surv. Israel.

Bishop, W. W., Miller, J. A. \& Fitch, F. G. 1969. New K-Ar age determinations relevant to the Miocene fossil mammal sequence in East Africa. Am. J. Sci. 267, 669-99. 
Blake, G. S. 1928. Geology and Water Resources of Palestine. Government of Palestine.

Brown, G. F. 1970. Eastern margins of the Red Sea and the coastal structures in Saudi Arabia. Phil. Trans. $R$. Soc. London A 267, 75-87.

Burdon, D. J. 1959. Handbook of the Geology of Jordan. Government of Hashemite Kingdom of Jordan.

Derin, B. \& Reiss, Z. 1973. Revision of marine Neogene stratigraphy in Israel. Isr. J. Earth Sci. 22, 199-210.

Freund, R. 1965. A model of the structural development of Israel and adjacent areas since Upper Cretaceous times, Geol. Mag. 102, 189-205.

Freund, R., Zak, I. \& Garfunkel, A. 1968. Age and rate of the movement along the Dead Sea Rift. Nature, Lond. 220, 253-5.

Freund, R. \& Zak, I. 1973. Shifting of folding and faulting along geological structures. Teva Ve'Aretz 15, 264-70 (in Hebrew).

Garfunkel, Z., Bartov, Y., Eyal, Y. \& Steinitz, G. 1974. Raham Conglomerate: new evidence for Neogene tectonism in the southern part of the Dead Sea Rift. Geol. Mag. 111, 55-64.

Garfunkel, Z. \& Horowitz, A. 1966. The Upper Tertiary and Quarternary morphology of the Negev. Israel J. Earth Sci. 15, 101-17.

Grader, P. \& Gvirtzman, G. 1961. Neogene gas prospects in the Central Coastal Plain, Israel. Bull. Res. Counc. Israel $10 \mathrm{G}, 147-72$.

Gvirtzman, G. \& Buchbinder, B. 1969. Outcrops of Neogene Formations in the Central and Southern Coastal Plain, Hashefela and Be'er Sheva Regions, Israel. Bull. geol. Surv. Israel 50, 1-52.

Horowitz, A. 1974. The Late Cenozoic Stratigraphy and Paleogeography of Israel. Tel Aviv University, Institute of Archaeology.

Kolodny, Y., Bar, M. \& Sass, E. 1974. Fission track age of the 'Mottled Zone Event' in Israel. Earth Planet. Sci. Lett. 11, 269-72.

Kolodny, Y., Schulman, N. \& Gross, S. 1973. Hazeva Formation affected by Mottled Zone Event. Israel J. Earth Sci. 22, 185-93.

Krenkel, E. 1924. Der Syrische Bogen. Centralbl. Mineral. 9, 274-81; 10, 301-13.

Meneisy, M. Y. \& Kreuzer, H. 1974. Potassium-argon age of Egyptian basaltic rocks. Geol. Jb. D 9, 21-31.

Michelson, H. 1972. The Hydrology of Southern Golan Heights. Tahal, Tel Aviv. Rep. HR/72/037.

Neev, D. \& Emery, K. O. 1967. The Dead Sea, depositional processes and environments of evaporites. Bull. Geol. Surv. Israel. 41, 1-147.

Picard, L. 1943. Structure and evolution of Palestine with comparative notes of neighbouring countries. Bull. Geol. Dept., Hebrew University, 1, no. 3.

Quennell, A. M. 1951. The Geology and Mineral Resources of (Former) Transjordan. Colonial Geology and Mineral Resources. London: H.M.S.O.

Quennell, A. M. 1959. Tectonics of the Dead Sea Rift. 20th Geol. Congr., Mexico, pp. 385-405.

Said, R., 1962. The Geology of Egypt, Elsevier.

Savage, R. J. G. \& Hamilton, W. R. 1973. Introduction to the Miocene mammal fauna of Gebel Zelten, Lybia. Bull. Mus. Hist. (Geol.) 22, 513-27.

Savage, R. J. G. \& Tchernov, E. 1968. Miocene mammals of Israel. Proc. geol. Soc. no. 1648; pp. 98-101.

Schulman, N. 1959. The geology of the Central Jordan Valley. Bull. Res. Counc. Israel. 8 G, 63-90.

Schulman, N. \& Rosenthal, E. 1968. Neogene and Quaternary of the Marma Feiyad area, south of Bet Shean. Israel J. Earth Sci. 17, 54-62.

Selly, R. C. 1969. Near shore marine and continental sediments of the Sirte Basin, Lybia. Q. Jl geol. Soc. Lond. 124, 419-60.

Shahar, Y. 1973. The Hazeva Formation of the Oron-Efe Syncline, Israel. Israel J. Earth Sci. 22, 31-49.

Siedner, G. 1973. K-Ar chronology of Cenozoic volcanics from Northern Israel and Sinai. Fortschr. Miner. 50, 129-30.

Siedner, G. \& Horowitz, A. 1974. Radiometric ages of Late Cainozoic basalts from Northern Israel: Chronostratigraphic Implications. Nature, Lond. 250, 23-36.

Wendt, I. 1969. Derivation of the Formula for a Regression Line Based on a Least-square Analysis. Internal Rep. Bundesanstalt für Bodenforschung, Hannover.

\section{G. S. \& Y. B.}

Mapping Division

Geological Survey of Israel

Jerusalem

Israel
J. C. H.

Department of Mineralogy

and Petrology

Sahlistr. 6

3012 Bern 